\title{
СОЛОДЕНКО А.Є.
}

Селекиійно-генетичний інститут - Національний центр насіннєзнавства та сортовивчення Національної академії аграрних наук України,

Україна, 65036,.м. Одеса, Овідіопольська дорога, 3, е-таil: angelika_solo@yahoo.com, (044) 789-55-56

\section{МАРКЕРИ ГЕНА АНАS1 ДЛЯ СКРИНІНГУ ТА ІДЕНТИФІКАЦІЇ ГЕНОТИПІВ СОНЯШНИКУ ГІБРИДНОГО ПОХОДЖЕННЯ}

Mета. Проведено скринінг гібридів $\mathrm{F}_{1}$ і $\mathrm{F}_{2}$ соняшнику за мікросателітними маркерами мутантного гена $A H A S 1$, асоційованого зі стійкістю до гербіцидів, що інгібують ацетолактатсинтазу. Методи. За допомогою ампліфікації фрагмента гена AHAS1, що містить мікросателітний повтор, досліджували стійкі до SU гербіцидів лінії SURES-1 та SURES-2; інбредні лінії селекції Селекційно-генетичного інституту; індивідуальні рослини $\mathrm{F}_{1}$ та сегреганти популяцій $\mathrm{F}_{2} . \mathbf{P e}$ зультати. Показана можливість ідентифікації гібридних рослин із різними алелями гена AHAS1. Доведена ефективність алеля 191 п. н. локусу AHASI в гомо- і гетерозиготному стані для маркерного добору генотипів, стійких до гербіцидів групи сульфонілсечовини. Отримано 10 гомозиготних рослин $\mathrm{F}_{2}$ популяції SURES-2 x OC $1019 \mathrm{~B}$ та 18 гомозиготних рослин $\mathrm{F}_{2}$ популяції SURES-2 х OC 1029B, які за генотипом відповідають лінії-донору мутантного гена AHAS1. Висновки. Присутність в генотипі рослини $\mathrm{F}_{2}$ алеля 191 п. н. локусу AHAS1 свідчить про стійкість до дії гербіцидів групи сульфонілсечовини і $є$ основою для проведення маркерного добору за цією ознакою. Рослини $\mathrm{F}_{2}-$ носії вказаного гена - в гомозиготному стані можуть бути використані як вихідний матеріал у селекції з метою створення нових інбредних ліній із генетично зумовленою стійкістю до SU гербіцидів.

Ключові слова: ДНК-маркери, ген AHAS1, соняшник, гербіциди, стійкість.

За новітніх агротехнологій захисту посівів соняшнику від бур'янів - Clearfield та ExpressSun, або Сумо - вирощують гібриди з генетично зумовленою стійкістю до гербіцидів групи імідазолінонів або сульфонілсечовини. Гербіциди, які належать до імідазолінонової та сульфонілсечовинної груп, інгібують фермент синтезу амінокислотних ланцюгів синтазу ацетогідроксикислоти (acetohydroxyacid synthase, AHAS), яка відома також як ацетолактатсинтаза (acetolactate synthase, ALS). Цей фермент є каталізатором першого етапу біосинтезу амінокислот із розгалуженим ланцюгом. Дія AHAS-інгібуючих гербіцидів призводить до фатального порушення метаболізму у чутливих до цих гербіцидів рослин [1]. Стійкість до гербіцидів, які інгібують AHAS, виникає у рослин у результаті точкових мутацій у генах, що кодують синтез цього ферменту. У більш ніж 80 видів рослин ідентифіковані природні біотипи, стійкі до AHASінгібуючих гербіцидів [2]. Популяції дикорослого соняшнику зі стійкістю до імідозолінонових (IMI) та сульфонілсечовинних (SU) гербіцидів уперше були знайдені у Канзасі та Південній Дакоті на полях, де застосовувалися гербіцидні обробки 7-8 років поспіль [3, 4]. Мутантні гени, які надають стійкості до AHAS-інгібуючих гербіцидів, були інтрогресовані зі зразків дикорослих популяцій (ANN-PUR та ANN-KAN) в елітні інбредні лінії з метою створення стійких сортів та гібридів $[5,6]$.

У соняшнику ідентифіковано три $A H A S$ гени (AHAS1, AHAS2, AHAS3) та визначена їх локалізація відповідно на 9, 6, 2 групах зчеплення генетичної карти і досліджена молекулярна структура цих генів [7]. Як і в $A H A S$ генів інших видів рослин, у соняшнику в межах цих генів не виявлено інтронів. Нуклеотидні послідовності AHAS генів відзначаються високим ступенем ідентичності. Так, AHAS2 відрізняється від AHAS1 за делецією 9 п. н. У свою чергу AHAS3 відрізняється від AHAS1 і AHAS2 наявністю двох делецій довжиною 3 та 9 п. н. За секвенування генів $A H A S$ дикого типу, які були клоновані зі сприйнятливих до дії гербіцидів генотипів соняшнику та мутантних варіантів $A H A S$, виділених зі стійких зразків, виявлено низку поліморфізмів. У послідовності AHASI ідентифіковано 48 однонуклеотидних замін (single nucleotide polymorphisms, SNPs) та варіацію за кількістю [АCС]n повторів; в структурі

С СОЛОДЕНКО А.є. 
гена AHAS2 детектована одна інерція-делеція (INDEL) довжиною 6 п. н.; мутантний ген AHAS3 відрізняється від гена дикого типу за одним SNP [8]. На молекулярно-генетичному рівні стійкість до IMI гербіцидів зумовлена заміною С-Т в кодоні 205 гена AHAS1; трансзиція С-Т в кодоні 197 призводить до появи стійкості до SU гербіцидів. У результаті вище згаданих точкових мутацій змінюється одна амінокислота в послідовності AHAS ферменту та його конформація, за якої фермент стає недоступним для дії гербіцидів.

ДНК-маркери, які щільно зчеплені з генами господарсько цінних ознак, дозволяють проводити маркерну селекцію (marker assisted selection, MAS), що значно полегшує контроль над переносом генів за схрещувань, дозволяє провести скринінг генетичних ресурсів для картування та маркування локусів, зчеплених із генами, що контролюють адаптивно значущі або корисні ознаки, та пошук донорів цільових генів, сприяє підвищенню ефективності добору. За допомогою маркерів здійснюють тестування вихідного селекційного матеріалу, беккросування та добір гомозигот у потомстві. Раніше за дослідження поліморфізму мікросателітної послідовності гена AHAS1 нами марковані лініїджерела стійкості до IMI та SU гербіцидів, які отримані 3 National Germplasm Resources Laboratory (North Central Regional PI Station, North Dakota, USA) [9].

Мета нашої роботи - скринінг гібридних популяцій соняшнику $\mathrm{F}_{1}$ та $\mathrm{F}_{2}$ за мікросателітними маркерами мутантного гена AHASI та ідентифікація гомозиготних сегрегантів-носіїв гена стійкості до SU гербіцидів.

\section{Матеріали і методи}

Як вихідний матеріал для дослідження використовували стійкі до SU гербіцидів лінії SURES-1 та SURES-2; інбредні лінії селекції Селекційно-генетичного інституту (СГІ-НЦНС): ОС 1019B, ОС 1029B, Од 973B, Од 5545B, Од $3171 \mathrm{~B}$; індивідуальні рослини $\mathrm{F}_{1}$ та сегреганти популяцій $\mathrm{F}_{2}$, отримані в результаті попарної ізоляції «кошик на кошик» та штучного запилення рослин без використання кастрації квіток від схрещувань: SURES-2 х OC 1029B, SURES-2 x OC 1019B, Од 5545B x SURES-1, Од 3171B x SURES-1.

Насіннєвий та рослинний матеріал для дослідження, а також відомості щодо фенотипової оцінки стійкості до дії гербіциду індивідуальних рослин $\mathrm{F}_{2}$ популяцій Од 5545B х SURES-1, Од 3171B x SURES-1 люб'язно надані завідувачем відділу селекції та насінництва гібридного соняшнику СГІ-НЦНС к. с.-г. н. Б.Ф. Вареником та провідним науковим співробітником к. с.-г. н. C.I. Карапірою.

ДНК виділяли цетавлоновим методом із сухого листя індивідуальних рослин або індивідуальних трьох-п'ятиденних проростків. Ампліфікацію здійснювали на приладі «Терцик» (ДНК-технологія, РФ). Склад реакційної суміші: буфер для DreamTaq полімерази, 1 одиниця активності DreamTaq полімерази (Fermentas, Литва), 0,2 мкМ кожного праймера, 0,2 мМ кожного dNTP, 20 нг ДНК. Умови ампліфікації: початкова денатурація 2 хв. $3 а 94{ }^{\circ} \mathrm{C}$; 30 циклів 20 с за $60^{\circ} \mathrm{C}, 30$ с за $72^{\circ} \mathrm{C}, 20$ с за $92^{\circ} \mathrm{C}$; фінальна елонгація 5 хв. Електрофоретичне розподілення продуктів ампліфікації проводили в поліакриламідному гелі (10\% акриламід, 1 х трисборатний буфер) 3 наступною візуалізацією азотнокислим сріблом. Документували отримані електрофореграми цифровою відеокамерою. Молекулярний розмір фрагментів ДНК визначали за допомогою програми «GelAnalyzer 2010» відносно маркерів довжини фрагментів ДНК: GeneRuler 50 bp, pUC 19 / MspI. Інформацію щодо нуклеотидних послідовностей праймерів для дослідження гена AHAS1 отримали $3[8]$.

\section{Результати та обговорення}

Ампліфікація фрагмента гена AHASl, що вміщує мікросателітний повтор, дозволила виявити низку поліморфних алелів та диференціювати досліджені лінії, які різняться за стійкістю до гербіцидів групи сульфонілсечовини. За використання пари праймерів pAHAS 16-17 у ліній SURES-1 та SURES-2 виявили алель 191 п. н. Лінії SURES-1 та SURES-2 мають спільне походження, донорами стійкості для цих ліній були окремі рослини популяції ANN-KAN дикорослого соняшнику Helianthus annuus L. B той же час вказані лінії відрізняються за педігрі. Так, наприклад, в родоводі SURES-1, окрім зразка ANN-KAN $H$. anпииs, $\epsilon$ присутні лінії HA 424, НA 406, НA 89; для створення SURES-2 залучалися лінії RHA 377, RHA 392 та RHA 376. За даними [8], стійкість до сульфонілсечовинних гербіцидів у ліній SURES-1 та SURES-2 пов'язана 3 точковою мутацією в кодоні 197 гена $A H A S 1$, яка призводить до заміни проліну на лейцин у молекулі синтази ацетогідроксики- 
слоти. У ліній селекції СГІ-НЦНС ОС 1019В, ОС 1029B, Од 973В, Од 5545B, Од 3171В виявили альтернативний алель 176 п. н. Отже, алелі локусу AHAS1 176 та 191 п. н. можуть бути рекомендовані як потенційні маркери для ідентифікації гібридних рослин $\mathrm{F}_{1}$ та добору 3 популяцій $\mathrm{F}_{2}$, що розщеплюються.

Під час аналізу насіння «потенційних» $\mathrm{F}_{1}$, одержаних від схрещування за індивідуальною схемою «кошик на кошик» лінії SURES-2 з лінією ОС 1019B або ОС 1029B та лінії SURES-1 3 лінією Од 973В без використання штучної кастрації рослин, одержані дещо різні результати. Оскільки рослини лінії SURES-1 та SURES-2 і ліній Од 973В, ОС 1019В та ОС 1029В є фертильними, то у кожному кошику як материнської, так і батьківської форми можливим було формування насіння як гібридної, так і самозапильної природи. Так, у комбінації схрещування SURES-1 х Од 973В в кошиках усіх рослин обох батьків було виявлено лише насіння з наявністю алелів 191 або 176 п н. відповідно, тобто гомозиготні генотипи від самозапилення. В комбінації схрещування SURES-2 х OC 1019B частка насінин із кошиків рослин лінії SURES-2 виявилася гетерозиготною за дослідженим локусом, тобто поєднувала алелі 191 та 176 п. н. від обох батьків. Інша частка насіння 3 кошиків рослин лінії SURES-2 за генотипом відповідала батьківській лінії, тобто таке насіння утворилося в результаті самозапилення. Насіння 3 кошиків рослин лінії ОС 1019В також було самозапильної природи.

Насіння $з$ гетерозиготним генотипом за локусом pAHAS 16-17 виявлено в кошиках із рослин SURES-2, які були задіяні в схрещуванні 3 ОС 1029B. У насінні 3 кошиків рослин лінії ОС 1029B виявлено гомозиготний генотип 3 алелем 176 п. н., який відповідає генотипу батьківської рослини ОС 1029B.

На наступному етапі з насіння, зібраного 3-під ізоляторів із кошиків рослин SURES-2, були вирощені рослини $\mathrm{F}_{1}$, проведена їх ізоляція і самозапилення. Для підтвердження гібридної природи для кожної рослини $\mathrm{F}_{1}$ маркерним аналізом визначали генотип за мікросателітним маркерним локусом $p A H A S$ 16-17, для чого використовували ДНК, виділену 3 листя. 3 кожної рослини $\mathrm{F}_{1}$, в генотипі якої виявлені алелі обох батьківських форм, тобто 176 та 191 п. н., отримали насіння $\mathrm{F}_{2}$.

Індивідуальні рослини $\mathrm{F}_{2}$ популяцій SURES-2 х OC 1019B та SURES-2 х OC 1029B
(24 та 57 шт. відповідно), що одержані від самозапилення гібридних рослин $\mathrm{F}_{1}$, досліджені за маркерним локусом $p A H A S$ 16-17 та за наявністю або відсутністю того або іншого алеля, розподілені на три генотипові класи.

Перший клас складали гомозиготні рослини, в генотипі яких присутній алель 191 п. н. лінії-донора мутантного гена AHASI SURES-2. До другого класу віднесені рослини, що $є$ носіями алеля 176 п. н., характерного для лінії ОС 1019B або ОС 1029B. Третій клас - гетерозиготні рослини, в генотипі яких $є$ алелі обох батьків. В обох комбінаціях схрещування SURES-2 х OC 1019B та SURES-2 х OC 1029B фактично одержане розчеплення $\mathrm{F}_{2}$ популяцій за алелями локусу pAHAS 16-17 1:2:1 відповідало теоретично очікуваному співвідношенню. Критерій відповідності $\chi_{\text {1:2:1 }}^{2}$ у першому схрещуванні дорівнював 4,92, а в другому - 1,74 , що значно менше $\chi_{0,05}^{2}=5,99$ для $\mathrm{df}=2$.

Загалом отримано 10 гомозиготних рослин $\mathrm{F}_{2}$ популяції SURES-2 х OC 1019B та 18 гомозиготних рослин $\mathrm{F}_{2}$ популяції SURES- $2 \mathrm{x}$ OC 1029B, які за генотипом відповідають лініїдонору мутантного гена AHASI.

Для оцінки ефективності використання цього маркера в практичній селекції порівнювали результати ідентифікації за алелями гена AHAS1 та стійкості до гербіцидів сульфонілсечовинної групи (Гранстар, діюча речовина тибенурон-метіл, 20 г/га) індивідуальних рослин $\mathrm{F}_{2}$ комбінацій схрещування Од $3171 \mathrm{~B}$ x SURES1 та Од 5545B x SURES-1. Для рослин, не стійких до дії гербіциду 3 пригніченим ростом $\mathrm{i}$ нетиповою морфологією, визначено гомозиготний генотип за маркерним локусом $P A H A S$ 1617 алелями, що відповідають батьківським лініям Од $3171 \mathrm{~B}$ та Од 5545B. Рослини $\mathrm{F}_{2}$, в генотипі яких поєднані маркерні алелі від обох батьківських ліній, виявилися стійкими до дії гербіциду, тобто однієї копії мутантного гена pAHAS1 достатньо для нормального розвитку рослин соняшнику на фоні гербіцидної обробки. Маркерним аналізом серед рослин $\mathrm{F}_{2}$ визначені ті, що містять дві копії мутантного гена $p A H A S 1$ і $є$ стійкими до дії гербіциду. Насіння з названих гомозиготних за алелем 191 п. н. стійких до гербіциду Гранстар рослин $\mathrm{F}_{2}$ комбінацій схрещування Од 5545B х SURES-1, Од 3171B х SURES-1, а також ідентифіковані за маркером гомозиготні рослини $\mathrm{F}_{2}$ популяцій SURES-2 x OC 1019B та SURES-2 x OC 1029B, що за гено- 
типом відповідають лінії-донору мутантного гена AHAS1, представляють найбільший інтерес iз погляду селекції. В наступних поколіннях самозапилення нащадків гомозиготних за маркером 191 п. н. рослин $\mathrm{F}_{2}$ можливе розчеплення за ознаками адаптивності, продуктивності та іншими, крім стійкості до SU гербіцидів, що дозволить проведення добору необхідних сегрегантів. Такі рекомбінантні сегреганти будуть складати основу вихідного матеріалу для селекційної роботи зі створення нових самозапильних ліній селекції СГІ-НЦНС, адаптованих для умов півдня України, з генетично зумовленою стійкістю до гербіцидів групи сульфонілсечовини та комплексом господарсько цінних ознак.

\section{Висновки}

Використання мікросателітного маркера дозволило ідентифікувати за алелями гена pAHAS1 генотипи ліній різного походження, гетерозиготні $\mathrm{F}_{1}$ та гомозиготні в $\mathrm{F}_{2}$ рослини. Розчеплення $\mathrm{F}_{2}$ популяцій за алелями гена pAHAS1 відповідало законам Менделя за відмінностей батьків за одним геном. Присутність у генотипі рослини $\mathrm{F}_{2}$ алеля 191 п. н. локусу AHAS1 в гомо- або гетерозиготному стані свідчить про стійкість до дії гербіцидів групи сульфонілсечовини і є основою для проведення маркерного добору за цією ознакою. Рослини $\mathrm{F}_{2}$ - носії вказаного гена - в гомозиготному стані можуть бути використані як вихідний матеріал у селекції 3 метою створення нових інбредних ліній із генетично зумовленою стійкістю до SU гербіцидів.

\section{Лiтература}

1. Duggleby R.G., Pang S.S. Acetohydroxyacid synthase. J. Biochem. Mol. Biol. 2000. Vol. 33. P. 1-36.

2. Heap I. The International survey of herbicide resistance weeds. URL: http:www.weedscience.org (Last accessed: 2.02.2007).

3. Al-Khatib K., Baumgartner J.R., Peterson D.E., Currie R.S. Imazethapyr resistance in common sunflower (Helianthus annuus). Weed Science. 1998. Vol. 46. P. 403-407.

4. White A.D., Owen M.D., Hartzler R.G., Cardina J. Common sunflower resistance to acetolactate-inhibiting herbicides. Weed Science. 2002. Vol. 50. P. 432-437.

5. Al-Khatib K., Miller J.F. Registration of four genetic stocks of sunflower resistant to imidazolinone herbicides. Crop Science. 2000. Vol. 40. P. 869-870.

6. Miller J.F., Al-Khatib K. Registration of two oilseed sunflower genetic stocks, SURES-1 and SURES-2, resistant to tribenuron herbicide. Crop Science. 2004. Vol. 44. P. 1037-1038.

7. Sala C., Bulos M., Echarte M. Genetic analysis of an induced mutation conferring imidasolinone resistance in sunflower. Theor. Appl. Genet. 2008. Vol. 118. P. 105-112.

8. Kolkman J., Slabaugh M., Bruniard J., Berry S., Bushman B., Olungu C., Maes N., Abratti G., Zambelli A., Miller J., Leon A., Knapp S. Acetohydroxyacid synthase mutations conferring resistance to imidasolinone or sulfonylurea herbicides in sunflower. Theor. Appl. Genet. 2004. Vol. 109. P. 1147-1159.

9. Солоденко A.С., Файт В.I. Маркери гена AHAS1 для використання в селекції соняшника на стійкість до гербіцидів. Вісник Харківського національного аграрного університету. Серія Біологія. 2015. Вип. 3 (36). С. 71-75.

\section{References}

1. $\quad$ Duggleby R.G., Pang S.S. Acetohydroxyacid synthase. J. Biochem. Mol. Biol. 2000. Vol. 33. P. 1-36.

2. Heap I. The International survey of herbicide resistance weeds. URL: http:www.weedscience.org (Last accessed: 2.02.2007).

3. Al-Khatib K., Baumgartner J.R., Peterson D.E., Currie R.S. Imazethapyr resistance in common sunflower (Helianthus annuus). Weed Science. 1998. Vol. 46. P. 403-407.

4. White A.D., Owen M.D., Hartzler R.G., Cardina J. Common sunflower resistance to acetolactate-inhibiting herbicides. Weed Science. 2002. Vol. 50. P. 432-437.

5. Al-Khatib K., Miller J.F. Registration of four genetic stocks of sunflower resistant to imidazolinone herbicides. Crop Science. 2000. Vol. 40. P. 869-870.

6. Miller J.F., Al-Khatib K. Registration of two oilseed sunflower genetic stocks, SURES-1 and SURES-2, resistant to tribenuron herbicide. Crop Science. 2004. Vol. 44. P. 1037-1038.

7. Sala C., Bulos M., Echarte M. Genetic analysis of an induced mutation conferring imidasolinone resistance in sunflower. Theor. Appl. Genet. 2008. Vol. 118. P. 105-112.

8. Kolkman J., Slabaugh M., Bruniard J., Berry S., Bushman B., Olungu C., Maes N., Abratti G., Zambelli A., Miller J., Leon A., Knapp S. Acetohydroxyacid synthase mutations conferring resistance to imidasolinone or sulfonylurea herbicides in sunflower. Theor. Appl. Genet. 2004. Vol. 109. P. 1147-1159.

9. Solodenko A.Ye., Fayt V.I. Markers of AHAS1 gene for use in sunflower breeding for resistance to herbicides. The Bulletin of Kharkiv National Agrarian University. Series Biology. 2015.3 (36). P. 71-75. 
SOLODENKO A.Ye.

Plant Breeding and Genetics Institute - National Center of Seed and Cultivar Investigation of National Academy of Agricultural Science of Ukraine,

Ukraine, 65036, Odessa, Ovidiopolskaya road, 3,e-mail: angelika_solo@yahoo.com

\section{DNA MARKERS OF AHASI GENE FOR SCREENING AND IDENTIFICATION OF SUNFLOWER GENOTYPES OF HYBRID ORIGIN}

Aim. A molecular genetic study of sunflower $\mathrm{F}_{1}$ and $\mathrm{F}_{2}$ hybrids on a microsatellite markers of mutant AHASl gene associated with herbicide resistance was performed. The aim of the work was to screen of $F_{1}$ and $F_{2}$ sunflower hybrid populations with usage of DNA markers and identification of homozygous segregants containing of the gene for resistance to SU herbicides. Methods. It was used PCR amplification to detect alleles of microsatellite locus located within the mutant AHAS1 gene. Results. The possibility of identification of hybrid plants with different alleles of the AHASI gene was shown. The efficiency of the allele of $191 \mathrm{~b}$. p. in the homo- and heterozygous state for marker selection of genotypes resistant to the herbicide of the sulfonylurea group was confirmed. 10 homozygous $\mathrm{F}_{2}$ plants of SURES- $2 \mathrm{x}$ OS 1019B and 18 homozygous $F_{2}$ plants of SURES-2 x OS 1029B, which according to the genotype correspond to the donor line of the mutant AHASI gene, were obtained. Conclusions. $\mathrm{F}_{2}$ plants that are carriers of this gene in the homozygous state can be used as an initial material in breeding for the purpose of creating new inbred lines with genetically determined resistance to $\mathrm{SU}$ herbicides.

Keywords: DNA markers, AHASI gene, sunflower, herbicides, resistance. 